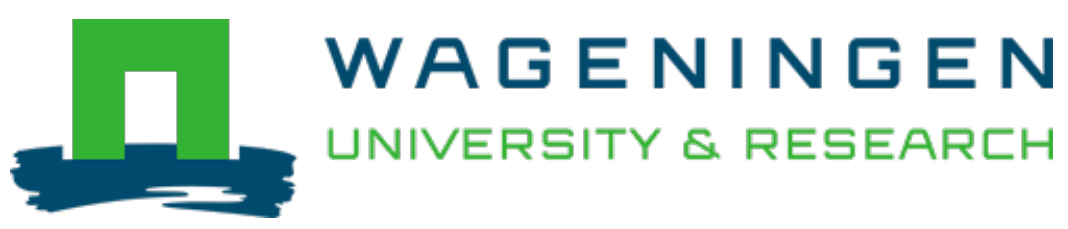

\title{
Prioritization of adaptation measures for improved agricultural water management in Northwest Bangladesh
}

\section{Climatic Change}

Acharjee, T.K.; Hellegers, P.J.G.J.; Ludwig, F.; Halsema, G.E.; Mojid, M.A. et al https://doi.org/10.1007/s10584-020-02852-w

This article is made publicly available in the institutional repository of Wageningen University and Research, under the terms of article $25 \mathrm{fa}$ of the Dutch Copyright Act, also known as the Amendment Taverne. This has been done with explicit consent by the author.

Article 25 fa states that the author of a short scientific work funded either wholly or partially by Dutch public funds is entitled to make that work publicly available for no consideration following a reasonable period of time after the work was first published, provided that clear reference is made to the source of the first publication of the work.

This publication is distributed under The Association of Universities in the Netherlands (VSNU) 'Article $25 \mathrm{fa}$ implementation' project. In this project research outputs of researchers employed by Dutch Universities that comply with the legal requirements of Article $25 \mathrm{fa}$ of the Dutch Copyright Act are distributed online and free of cost or other barriers in institutional repositories. Research outputs are distributed six months after their first online publication in the original published version and with proper attribution to the source of the original publication.

You are permitted to download and use the publication for personal purposes. All rights remain with the author(s) and / or copyright owner(s) of this work. Any use of the publication or parts of it other than authorised under article $25 \mathrm{fa}$ of the Dutch Copyright act is prohibited. Wageningen University \& Research and the author(s) of this publication shall not be held responsible or liable for any damages resulting from your (re)use of this publication.

For questions regarding the public availability of this article please contact openscience.library@,wur.nl 


\title{
Prioritization of adaptation measures for improved agricultural water management in Northwest Bangladesh
}

\author{
Tapos Kumar Acharjee ${ }^{1}$ (D) Petra Hellegers ${ }^{2}$ • Fulco Ludwig ${ }^{3}$ - Gerardo van Halsema ${ }^{2}$. \\ Md. Abdul Mojid ${ }^{1} \cdot$ Catharien Terwisscha van Scheltinga $^{4}$
}

Received: 13 July 2019 / Accepted: 26 August 2020/Published online: 01 September 2020

(C) Springer Nature B.V. 2020

\begin{abstract}
Adaptation strategies are essential to manage water demand and ensure optimal use of available water resources under climate change. Identification and prioritization of adaptation options would greatly support decision-making in drought-prone Northwest Bangladesh. This study identified climate adaptation options by literature review and stakeholder consultation, then used multi-criteria analysis to evaluate and prioritize the options. The complexity of the options was also evaluated, specifically social, institutional, and technical obstacles to their local uptake. Seventy-two adaptation options were identified, spanning six sector categories. The options were further classified as in-system dependent, i.e., options that could be implemented by local actors, or as out-system dependent, i.e., options reliant on actions by external actors. Finally, they were defined as on-farm or off-farm strategies. Transboundary cooperation to increase surface water flows was ranked as the overall top-priority option, though this option is very complex and out-system dependent. Integrated water resources management and integrated crop management were the top-ranked options in the water management and crop production management sectors, respectively. Clustering scattered households and offering training programs in on-farm water management were the most and least complex measures, respectively. Stakeholders exhibited a clear preference for higher scale out-system dependent strategies, rather than in-system dependent options focused on changing the agricultural system itself to cope with climate change. Nonetheless, it is recommended that short-term and medium-term planning focus on opportunities to implement achievable adaptation measures within the local agricultural system. Investment in complex, externally dependent strategies is important for long-term planning.
\end{abstract}

Keywords Climate change $\cdot$ Ranking alternatives $\cdot$ Multi-criteria analysis

Tapos Kumar Acharjee tapos.bau@gmail.com

Extended author information available on the last page of the article 


\section{Introduction}

Climate change adaptation is nowadays a national priority in Bangladesh. The Bangladesh Climate Change Strategy and Action Plan (BCCSAP) identifies three main climate hazards: tropical cyclones/storm surges, inland flooding, and drought. Already the country faces reduced cultivable area as a result of urbanization and industrial growth, combined with falling groundwater levels, reduced surface water availability in the dry season, and rising food demand due to the growing population. In Northwest Bangladesh, the groundwater table fell by 2.3-11.5 m from 1981 to 2011 (Dey et al. 2013), due to overexploitation of water for irrigated rice cultivation (Shahid and Hazarika 2010) and low recharge potential (Adham et al. 2010). A major challenge for future agricultural production in this region is sustainable water management under the impacts of climate change, particularly in conditions of drought and high-temperature stress.

Climate models for South Asia project decreased dry season precipitation and increased monsoon rainfall (Christensen et al. 2007; Shahid and Behrawan 2008). Rainfall is also expected to become more erratic and unpredictable, with more frequent droughts. The consequences of droughts can be even more devastating than those of a cyclone or flood (Shahid 2008; Shahid and Behrawan 2008). Surface water flows are expected to increase in the monsoon season, but decrease in the winter months over the coming decades. According to Selvaraju and Baas (2007), a temperature increase of $1.3{ }^{\circ} \mathrm{C}$ combined with a $9 \%$ drop in precipitation by 2050 will reduce surface runoff into the Ganges, Brahmaputra, and Meghna rivers by $27 \%, 21 \%$, and $15 \%$, respectively. This would make agriculture in Northwest Bangladesh increasingly vulnerable. Adaptation planning is therefore needed to safeguard the country's future food production potential.

Adaptation planning is essential to cope with climate change. Planned adaptations refer to actions to be taken to minimize the risks of climate change and to maximize opportunities, the aim being to reduce vulnerability (Smit and Pilifosova 2003). Adaptation planning is a process of deciding what should be done, to what extent (more, less or differently) by whom, and with what resources (Füssel 2007). Anticipatory adaptation planning entails a series of forwardlooking steps, particularly an assessment of recent and future vulnerabilities, identification of adaptation options, prioritization of the identified options, implementation of prioritized options, and monitoring and evaluation of implementation progress (Champalle et al. 2015). Successful identification and assessment of adaptation options is a prerequisite for effective adaptation planning (Füssel 2004). Prioritization is a way of indicating which measures should be considered for implementation first.

Approaches for assessing adaptation measures are broadly grouped into two categories: hazard-based approaches and vulnerability-based approaches (Lim et al. 2005). In hazardbased approaches, model-based climate change projections serve as the starting point; hence, there is limited consideration of non-climatic factors. Vulnerability-based approaches, in contrast, start from past experience in managing recent climate risks; stakeholders are thus directly involved in the assessment of adaptation options (Füssel 2007). Hazard-based approaches are most useful for raising awareness of a problem and identifying research priorities. Vulnerability-based approaches are most useful for assessing the effectiveness of a specific intervention, especially in contexts where resources - such as data, expertise, time, and money_are limited (Füssel 2007).

Adaptation planning must always be context specific, as a region's own environmental, climatic, social, and political conditions have to be considered (Shepherd et al., 2006; Swart 
and Raes 2007). To incorporate contextual aspects, involvement of local experts and stakeholders is recommended. Furthermore, specification of policy priorities for a particular context promotes successful implementation of adaptation plans (Bierbaum and Stults 2013). Lobell et al. (2008) found that in South Asia, adaptation priorities differed markedly across crop types and also that priorities depended on the risk attitudes of investment institutions. Regarding operational adaptation measures, involving local stakeholders can contribute to effective priority setting.

Adaptation planning thus starts with identification of the different options that could potentially be effective in a local context. The next step is to decide which measures among the identified options are to be preferred (Smit and Wandel 2006). Ranking of options ensures (i) that the best options are the first ones subjected to evaluation, testing, or implementation; (ii) that better options are not skipped in favor of counterproductive or less beneficial ones; and (iii) that the best possible actions are taken in contexts where resources are scarce.

Adaptation actions are closely linked to development activities, and this connection must be considered when evaluating adaptation options (Smit and Pilifosova 2003). Moreover, adaptation actions may be constrained by a variety of social and individual factors (Adger et al. 2009). In developing countries, a foremost challenge is the need to build adaptive capacity while also addressing the impacts of climate change, in the context of competing development objectives (Adger et al. 2003). Ranking options provides a way to incorporate longer term aspects of climate adaptation into ongoing development-oriented planning.

While some studies have identified adaptation options for water management in Northwest Bangladesh, none has set priorities among these options. Furthermore, the available research on potential climate change adaptations for this region compares only a very limited set of adaptation options. No studies compare a wide array of potential responses. In addition, most previous work focuses on economic evaluation of identified options, rather than rankings based on stakeholders' views regarding potential vulnerabilities due to climate change. The current study fills this void, thereby extending past work in this field.

Agriculture, water availability, and water demand are all sensitive to climate conditions. Agricultural systems can be adapted to changing conditions, but they have varying degrees of capacity to cope with climate change (Feenstra 1998; Reilly 1995). In a developing country such as Bangladesh, with poor economic conditions, scarce water resources, and a rapidly growing population, management of water for agriculture is an enormous challenge. Farmers usually cope with the problems that arise by adjusting local practices. For example, farmers in Northwest Bangladesh have adapted to drought by introducing new agronomic practices, water resource exploitation methods, and crop intensification (Habiba et al. 2012). Some new practices, such as the withdrawal of large quantities groundwater via deep tubewells, could become ineffective or detrimental in the long term. This points to the need to consider sustainability issues under climate change when assessing adaptation options for the long term.

Different methods are available for ranking alternatives (de Bruin et al. 2009), such as costbenefit analysis (CBA), cost-effectiveness analysis (CEA), and multi-criteria analysis (MCA). Even with the use of such methods, the evaluation of costs and benefits of climate change adaptation options remains difficult, due to the uncertainty inherent in climate change projections. For a developing country like Bangladesh, prioritization of adaptation options based on social cost-benefit analysis is made particularly problematic by limited data availability and lack of an agreed method. Füssel (2009) observed that prioritization of national-level adaptation measures based on social cost-benefit analysis is not feasible even for countries with highly developed economic, institutional, and technical capacity. The United Nations (UN) has 
advocated MCA as the preferred method for least-developed countries to prioritize climate adaptation options (Brooks et al. 2009). Multi-criteria decision analysis is said to be coherent with real decisions and able to support real decision processes (Boettle et al. 2013). Moreover, different stakeholders' interests can be incorporated into decision processes using MCA.

In the current study, we used MCA to assess and prioritize identified adaptation options. Furthermore, we investigated the social, institutional, and technological complexities associated with implementing adaptation measures in the context of Northwest Bangladesh.

\section{Methodology}

\subsection{Identification of adaptation options}

Our study focused on both current agricultural practice and possible future vulnerabilities due to climate change in Northwest Bangladesh. The study region extends from $23^{\circ} 47^{\prime} \mathrm{N}$ to $25^{\circ}$ $50^{\prime} \mathrm{N}$ latitude and from $88^{\circ} 01^{\prime} \mathrm{E}$ to $89^{\circ} 48^{\prime} \mathrm{E}$ longitude, thus belonging to the sub-humid agro-climatic class. Dry season meteorological drought is very common here (Shahid and Behrawan 2008). Rice is the main crop, with $31 \%, 56 \%$, and $13 \%$ of land used for single, double, and triple cropping, respectively (Shahid and Hazarika 2010).

Figure 1 presents the methodological steps followed in this study. Adaptation options were first identified based on a literature review and consultation with experts and stakeholders. The listed options were then more closely examined and a short list prepared omitting repetition. Though some of the identified options were closely linked, we considered them separate if they concerned different sectors and management strategies. With regard to sector, the identified adaptation options were grouped into six categories: crop production management, land use management, water management, environmental management, social and institutional management, and education and research. The options were further classified as in-system dependent, i.e., as options that could be implemented by local actors on their own, or as outsystem dependent, i.e., options reliant on actions taken by entities outside local farmers and agricultural or water management authorities. Finally, they were categorized as either on-farm strategies, that is, strategies that could be implemented at the farm/community level, or as offfarm strategies, that is, having to be implemented by a body or authority beyond the farm/ community level (Table 1). Though, as Noble et al. (2014) observed, there is no universally agreed way to categorize climate change adaptation options, this categorization scheme allowed us to consider key differences between options across a range of different sectors and stakeholders.

\subsection{Prioritization of adaptation options}

Following the evaluation criteria used by De Bruin et al. (2009) for ranking adaptation options in The Netherlands, we prioritized the options by applying four criteria: importance, urgency, no-regret, and co-benefits. These criteria are broad, which enabled them to be operationalized for all of our categories of adaptation options. "Importance" concerns the capacity or effectiveness of an option in preventing or avoiding negative impacts and taking advantage of positive impacts of climate change. A highly important option is thus one that can greatly reduce the detrimental impacts of climate change. "Urgency" concerns the timing of an option's implementation. It relates to how quickly an adaptation option must be implemented 


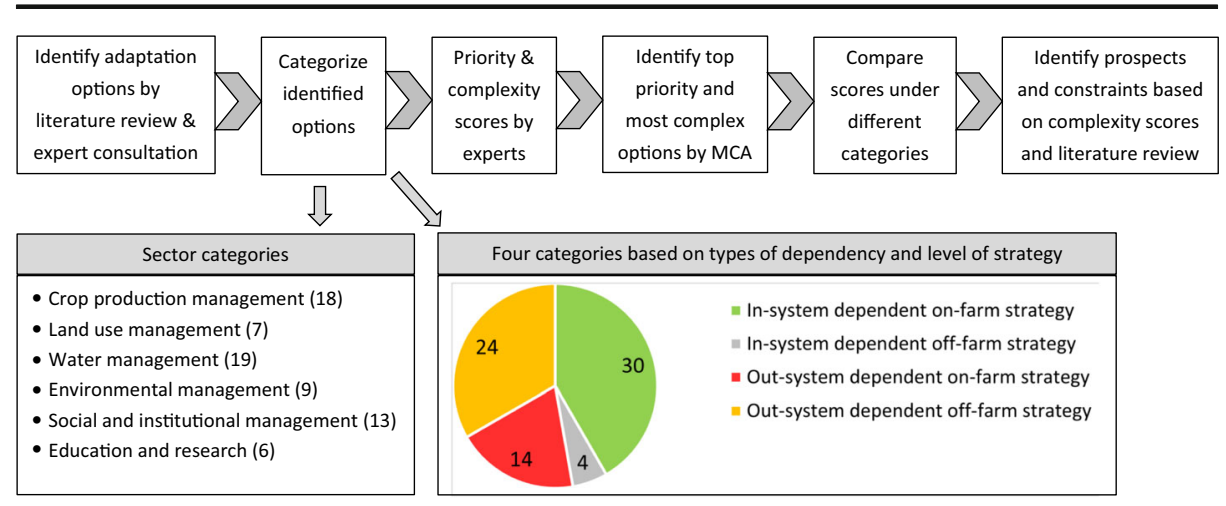

Fig. 1 Methodological steps followed in this study and categorizations of adaptation options

to address a current or imminent problem. Options that are highly urgent must be implemented immediately to curb or stop negative effects of climate change. However, an option with a high score on urgency will not always become a top priority, as a measure can be urgent if delayed implementation would bring higher costs or irreversible small damages (de Bruin et al. 2009). "No-regret" concerns an option's usefulness under variable situations, in other words, its flexibility. An option that scores highly on the no-regret criterion would be appropriate whether the impacts of climate change turned out to be larger or smaller than expected. Noregret options can thus be justified under all plausible future scenarios (Willows et al. 2003). "Co-benefits" indicates that an option also makes contributions to other sectors or objectives (e.g., poverty alleviation).

To assess priority of different adaptation options, we consulted with experts having indepth knowledge about the specific problems of agriculture in the study region of Northwest Bangladesh. Among those consulted were officials from the Bangladesh Agricultural Development Corporation (BADC), the Bangladesh Agricultural Research Institute (BARI), the Bangladesh Rice Research Institute (BRRI), the Bangladesh Sugarcrop Research Institute (BSRI), the Bangladesh Institute of Nuclear Agriculture (BINA), the Department of Agricultural Extension (DAE), the Rural Development Academy (RDA), the Bangladesh Agricultural University (BAU), Sylhet Agricultural University (SAU), and the Bangabandhu Sheikh Mujibur Rahman Agricultural University (BSMRAU). Identified 72 adaptation options were

Table 1 Classification of options for adapting to climate change

\begin{tabular}{ll}
\hline Type & Explanation \\
\hline $\begin{array}{l}\text { In-system } \\
\text { dependent }\end{array}$ & $\begin{array}{r}\text { Measures that are implementable by local water managers or farmers without dependence on } \\
\text { external systems or bodies. For example, local agricultural or water management } \\
\text { authorities can adjust their irrigation method themselves (e.g., shifting from basin/furrow } \\
\text { irrigation to drip/sprinkler irrigation). Such an adjustment is therefore an in-system } \\
\text { dependent } \text { option. }\end{array}$ \\
$\begin{array}{l}\text { Measures that rely on systems or bodies other than local farmers and agricultural or water } \\
\text { management authorities for successful implementation. For example, development and } \\
\text { dissemination of new irrigation technologies depends on policy support for research and } \\
\text { extension (e.g., promotion of solar irrigation in areas without electricity). Such an option } \\
\text { is therefore out-system dependent. } \\
\text { Measures that can be implemented at the farm/community level. } \\
\text { Measures that must be implemented beyond the farm/community level. }\end{array}$ \\
Off-farm
\end{tabular}


judged by 30 experts/stakeholders in 2016 and 2017. These options were prioritized using MCA. As noted, MCA is a well-established method which has been employed in numerous previous studies (e.g., Agrell et al. 1998; Almasri and Kaluarachchi 2005; Joubert et al. 2003; Raju and Kumar 1999) for national-level rankings of adaptation alternatives (Greco et al. 2016).

Before asking the experts/stakeholders to provide their judgments on the adaptation options, we asked them to weight the four criteria. We then prompted them to consider the 72 adaptation options and assign each a numerical score of 1-5 on each prioritization criterion (4). These scores represented their judgments about each option. This step was subject to various biases. For example, it was influenced by the individual experts' own ideas about possible future conditions, their job type, and their posting. Nonetheless, this study did not differentiate between types of experts/ stakeholders. The adaptation options were then ranked according to the final weighted score per option.

The weighted scores were calculated as follows:

$$
W S_{x i}=W_{i} \times S_{x i}
$$

where $W S_{x i}$ is the weighted score of option $x$ under criterion $i, W_{i}$ is the weight of criterion $i$ assigned by an individual expert/stakeholder, and $S_{x i}$ is the score for option $x$ under criterion $i$ assigned by an individual expert/stakeholder.

The final score under each criterion was calculated as follows:

$$
F S_{x i}=\frac{\sum W S_{x i}}{\sum W_{i}}
$$

where $F S_{x i}$ is the final score for option $x$ under criterion $i$.

The average score for the four criteria was used for prioritizing the adaptation option.

\subsection{Assessment of complexity}

"Complexity" indicates the level of difficulty of implementing an option under the prevailing local conditions. We used MCA to assess the complexities involved in each potential adaptation option, following a procedure similar to that discussed in Section 2.2. Following De Bruin et al. (2009), we assessed the overall complexity of the identified adaptation options by applying three criteria: technical complexity, social complexity, and institutional complexity. Thus, each expert/stakeholder was asked to assign a weight to the three complexity criteria before giving a complexity score to each of the options (72). A high score on complexity indicates that an adaptation option is difficult to implement with the current level of technical capacity, social acceptance, and institutional setup in the study region.

"Technical complexity" entails difficulty due to, for example, a lack of technical expertise or instrumentation to implement an option. "Social complexity" indicates a difficulty in convincing farmers and other practitioners to implement an option. "Institutional complexity" indicates institutional weakness or lack of an appropriate institutional setup to implement an option. The authors, moreover, reviewed recently published scientific articles and gray literature to explore the technical, social, and institutional dimensions of adaptive capacity in Northwest Bangladesh. 


\section{Results}

\subsection{Identified adaptation options}

Our inventory of adaptation options included 18 crop production management options, 7 land use management options, 19 water management options, 9 environmental management options, 13 social and institutional management options, and 6 education and research options. Tables 5, 6, 7, 8, 9, and 10 in the Appendix list all of these. Some are very specific (e.g., alternate wetting and drying (AWD), rainwater harvesting), while others are very broad (e.g., integrated water resources management (IWRM), integrated crop management (ICM)). This study's identification of adaptation measures did not focus on any specific scale, type, level, or approach. Thus, some of the options proposed would directly reduce the water required for crop production (e.g., rainfed agriculture, deficit irrigation, AWD) or increase water availability (e.g., enhancing sluice or weir capacity, transboundary cooperation to increase surface water flows). Others targeted long-term sustainable use of water resources (e.g., agroenvironmental schemes, water pollution control) or indirect improvements in water management to cope with climate change impacts. We grouped these options according to whether they represented in-system or out-system actions and whether they constituted on-farm or offfarm strategies. Most of the options, 30\%, were found to be in-system dependent on-farm strategies, while $24 \%$ were out-system dependent off-farm strategies, $14 \%$ were out-system dependent on-farm strategies and $4 \%$ were in-system dependent off-farm strategies (see Fig. 1).

\subsection{Top-priority options}

Table 2 presents the top ten prioritized adaptation options. Two of these were crop production management options (16 and 3), one was a land use management practice (23), four were water management measures $(29,27,31$, and 26), one was a social/institutional approach (58), and two were education and research related (69 and 67). Transboundary cooperation to increase surface water flows received the highest overall score across all criteria. No environmental management measure obtained a high enough score to place it in the top ten. The highest ranked environmental management option was waste management to reduce water pollution. Figure 2 compares the average weighted prioritization scores by sector categories. Education and research-related activities received the highest overall priority score (3.61). The average weighted scores for social and institutional management, water management, environmental management, crop production management, and land use management were 3.33, $3.32,3.13,3.01$, and 2.87, respectively. Most of the top-priority options represented outsystem dependent on-farm strategies (see Table 2). Only three in-system measures-i.e., options that could be implemented autonomously by local agricultural water managers or farmers - were among the top ten ranked options. Thus, our results point to a preference among stakeholders for out-system dependent on-farm strategy options (see Fig. 3). In-system dependent on-farm strategy options were considered least promising by experts/stakeholders.

\subsection{Most complex options}

Regarding complexity, the ten most complex measures as identified by experts/stakeholders included one crop production management option (15), two land use management practices 


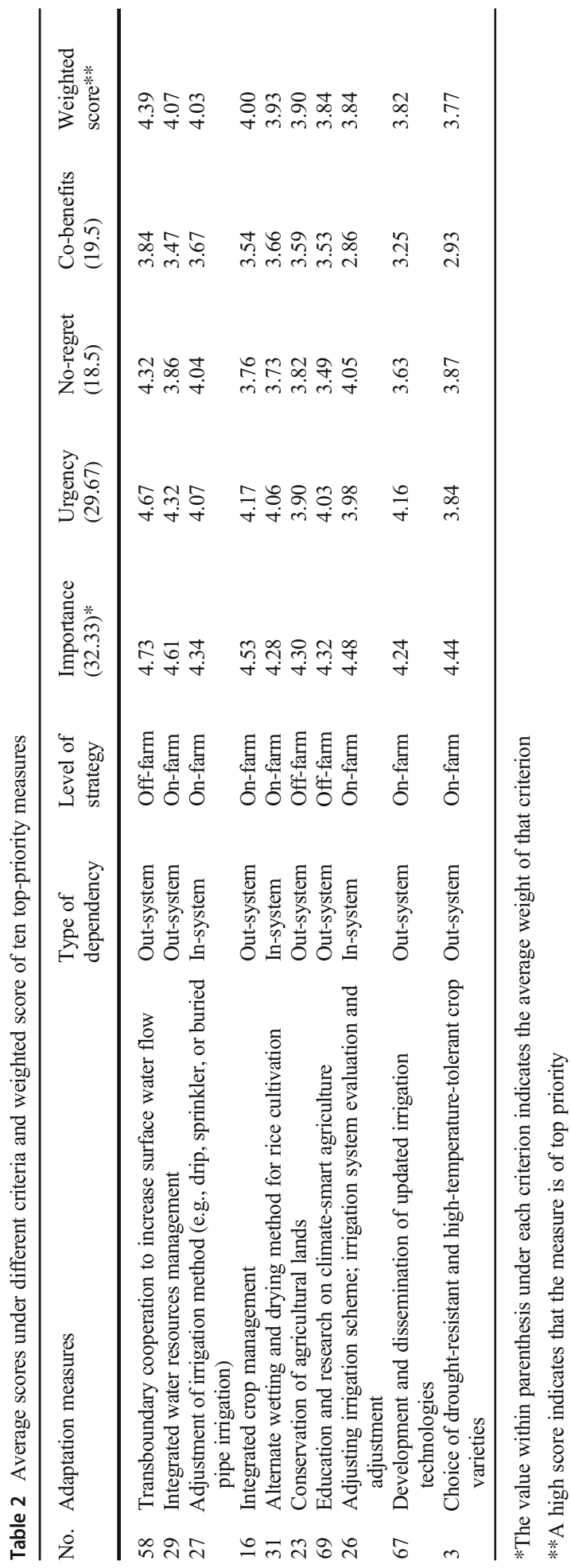




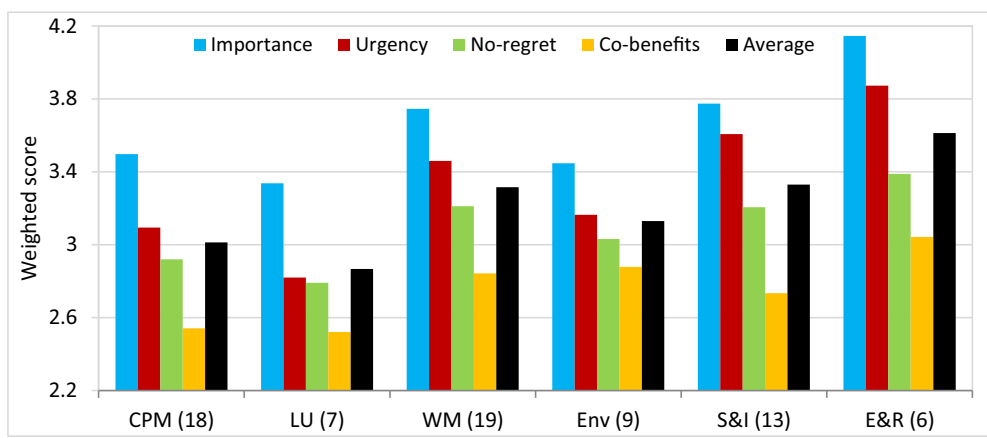

Fig. 2 Weighted scores and averages for prioritization criteria, by the six adaptation option sectors, i.e., crop production management (CPM), land use management (LU), water management (WM), environmental management (Env), social and institutional management (S\&I), and education and research (E\&R)

(21 and 19), two water management measures (41 and 33), three environmental management measures (50, 46, and 48), and two social/institutional approaches (58 and 65) (Table 3). Increasing croplands by clustering scattered households received the highest weighted score on complexity (3.86), making it the most complex adaptation option of the inventory. None of the ten most complex options was in the education and research category. Transboundary cooperation to increase surface water flows was the only option to appear both among the top ten prioritized options and the ten most complex options; it was also the most complex option in the institutional complexity category.

Three crop production management options (18, 14, and 5), one land use management practice (22), two water management measures (31 and 38), three social/institutional approaches $(61,63$, and 62), and one education and research option (72) received the lowest complexity scores and were thus ranked as the ten least complex options to implement. Training programs in on-farm water management emerged as the least complex adaptation option. None of the environmental management options fell within the ten least complex options to implement. From a technical viewpoint, rainfed crop cultivation was the least complex measure to implement, while developing meteorological stations to support better forecasting was the least complex measure from a social point of view. AWD irrigation for rice cultivation was found to be the least complex measure from an institutional viewpoint. This

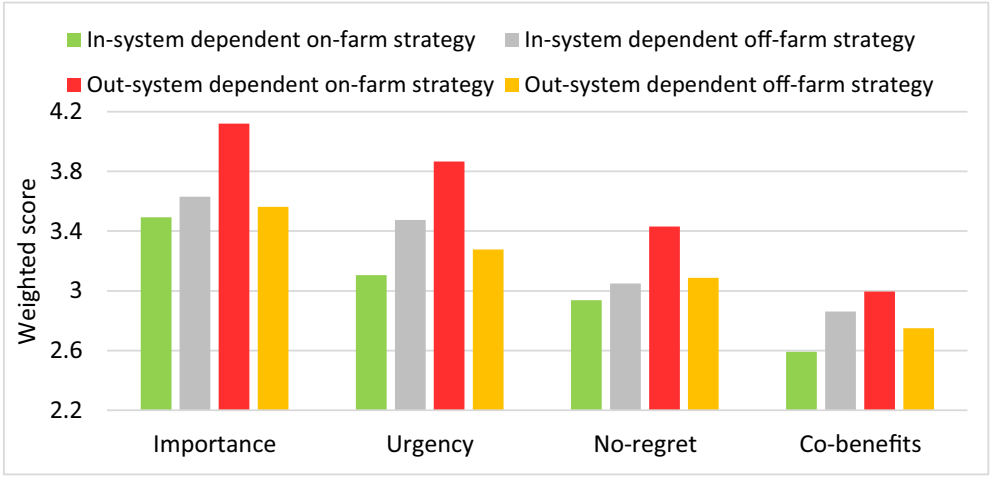

Fig. 3 Average weighted scores for adaptation option characteristics, by the four prioritization criteria 
Table 3 Ten most complex options, according to weighted average of scores on the three complexity criteria

\begin{tabular}{|c|c|c|c|c|c|}
\hline No. & Adaptation measures & $\begin{array}{l}\text { Technical } \\
(36.5)^{*}\end{array}$ & $\begin{array}{l}\text { Social } \\
(34.33)\end{array}$ & $\begin{array}{l}\text { Institutional } \\
(29.17)\end{array}$ & $\begin{array}{l}\text { Weighted } \\
\text { score }^{* *}\end{array}$ \\
\hline 21 & $\begin{array}{l}\text { Increasing crop lands by clustering scattered } \\
\text { households }\end{array}$ & 3.87 & 4.12 & 3.61 & 3.86 \\
\hline 19 & Relocation or mobilization of farms & 3.61 & 4.04 & 3.10 & 3.58 \\
\hline 50 & Restoration of ecosystems & 3.79 & 2.88 & 3.82 & 3.50 \\
\hline 46 & Waste management to reduce water pollution & 3.60 & 3.43 & 3.34 & 3.46 \\
\hline 41 & $\begin{array}{l}\text { Fair (re)allocation of water among different regions } \\
\text { (more to affected areas) }\end{array}$ & 3.26 & 3.45 & 3.35 & 3.35 \\
\hline 58 & $\begin{array}{l}\text { Transboundary cooperation to increase surface } \\
\text { water flow }\end{array}$ & 3.22 & 2.47 & 4.33 & 3.34 \\
\hline 65 & Climate risk management measures & 3.58 & 2.96 & 3.48 & 3.34 \\
\hline 15 & $\begin{array}{l}\text { Construction of greenhouses/crop houses for fruits } \\
\text { and vegetables cultivation }\end{array}$ & 3.44 & 3.55 & 3.02 & 3.34 \\
\hline 33 & Reconnection of water systems & 3.84 & 2.78 & 3.34 & 3.32 \\
\hline 48 & $\begin{array}{l}\text { Implementation of effective agro-environmental } \\
\text { schemes }\end{array}$ & 3.37 & 2.97 & 3.58 & 3.31 \\
\hline
\end{tabular}

*The value within parenthesis under each criterion indicates the average weight of that criterion

**A high score indicates that the measure is more complex to implement

was the only option that appeared both among the top ten priorities and the ten least complex adaptation options.

Figure 4 presents average weighted complexity scores grouped by sector. Here we see high social complexity with lower technical and institutional complexity for the crop production management options. We found high technical, social, and institutional complexity for land use management and environmental management options. Water management options showed medium-level complexity on all three complexity criteria. A medium level of technical complexity, with low-level social complexity and high-level institutional complexity, was found for social and institutional approaches and for education and research-related options.

Results indicate a relatively low technical and institutional complexity for the options categorized as in-system dependent on-farm strategies, compared with the other categories (Fig. 5). Technical and institutional complexity was found to be highest for the options representing out-system dependent off-farm strategies. Options with out-system dependence,

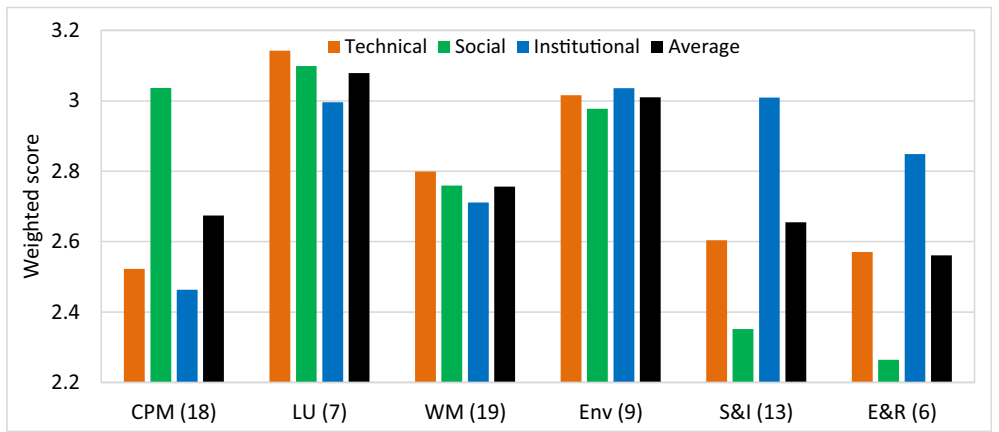

Fig. 4 Weighted scores and averages for the three types of complexities, by the six adaptation option sectors, i.e., crop production management (CPM), land use management (LU), water management (WM), environmental management (Env), social and institutional management (S\&I), and education and research (E\&R) 


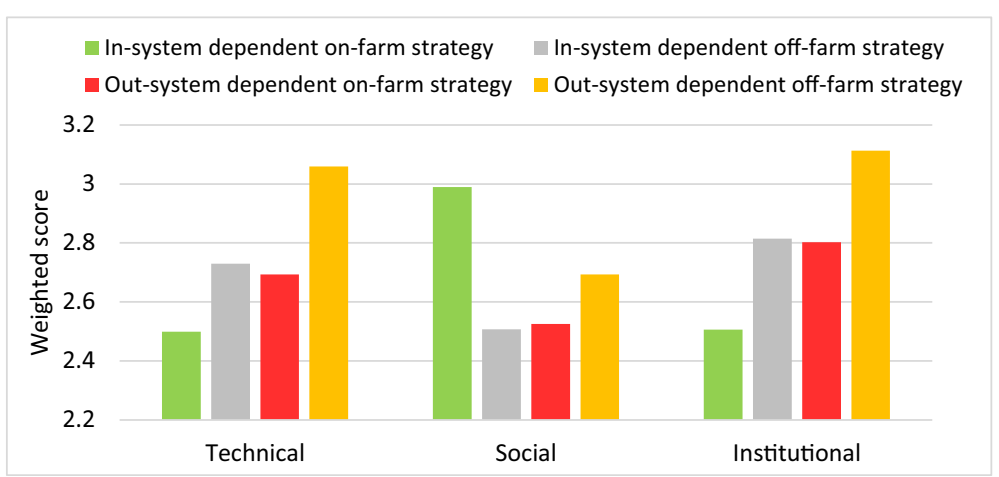

Fig. 5 Average weighted scores for adaptation option characteristics, by the three types of complexities

combined with either an on-farm or off-farm strategy, entailed higher technical and institutional complexities than the in-system dependent on-farm strategies.

Table 4 summarizes prospects and constraints relating to the technical, social, and institutional dimensions of adaptive capacity in agricultural water management in Northwest Bangladesh. The overview reveals possible reasons for the high social, institutional, and technical complexities found in our results. Actions to eradicate these complexities could include greater availability of facilities such as economic assistance and training programs for farmers, alongside institutional capacity development and technological resource development.

\section{Discussion}

\subsection{Inventory of adaptation measures}

Our inventory of adaptation options spans a broad range of measures applicable to Northwest Bangladesh. Most of these options hold promise not only for Bangladesh but also beyond, in many other regions of the world. However, the capacity, suitability, and feasibility of these options for dealing with local-level climate change impacts will differ from region to region. For example, AWD is an option that applies only to rice-cultivating regions. Also, no salinity management measures were included in our inventory, as salinity intrusion is not a problem relevant to Northwest Bangladesh. The purpose of our inventory of adaptation options was not to limit the investigation to the identified measures but to provide an overview of all possible actions, with the aim of moving the planning process forward and contributing to effective decision-making. The purpose of prioritizing the identified options was to enable and accelerate effective actions for better agricultural water management.

\subsection{Top-priority measures: recent progress and future prospects}

Transboundary cooperation to increase dry season surface water flows was identified as the top-priority option. Indeed, this is a vital issue for sustainable development in Bangladesh, as the country has 57 transboundary rivers, most of which are distributaries that originate outside its borders (Chowdhury 2010). BDP2100 (2017) also identified transboundary cooperation as an important measure in the Ganges-Brahmaputra basin. However, it is one of the most 
Table 4 Prospects and constraints related to technical, social and institutional dimensions of adaptive capacity for water management in Northwest Bangladesh

\begin{tabular}{|c|c|c|c|}
\hline $\begin{array}{l}\text { Adaptive } \\
\text { capacity }\end{array}$ & Prospects & Constraints & References \\
\hline Social & $\begin{array}{l}\text { - Farmers in Northwest Bangladesh } \\
\text { can identify recent climatic } \\
\text { changes } \\
\text { - People are changing livelihood } \\
\text { practices with the changing } \\
\text { climate } \\
\text { - Farmers have capacity to } \\
\text { autonomously adjust to some } \\
\text { changes } \\
\text { - Farmers seek solutions for drought } \\
\text { Nursey-Bray (2017) }\end{array}$ & $\begin{array}{l}\text { - Existing level of adaptation by farmers is } \\
\text { limited } \\
\text { - Large number of vulnerable smallholder } \\
\text { farmers } \\
\text { - Poor economic conditions of farmers } \\
\text { limit their uptake of expensive but } \\
\text { effective adaptive solutions } \\
\text { - Lack of awareness } \\
\text { - Lack of secured land tenure rights } \\
\text { - Inadequate credit support to farmers }\end{array}$ & $\begin{array}{l}\text { Anik and } \\
\text { Khan } \\
(2012) ; \\
\text { Habiba et al. } \\
\text { (2012); } \\
\text { Islam and }\end{array}$ \\
\hline Institutional & $\begin{array}{l}\text { - Responsible institutions can initiate } \\
\text { activities toward capacity building } \\
\text { - Policy-level contributions are being } \\
\text { made by institutions } \\
\text { - Responsible institutions have } \\
\text { formulated several adaptation } \\
\text { programs } \\
\text { - Better negotiation capacity within } \\
\text { local institutions } \\
\text { - Responsible institutions have } \\
\text { mainstreamed climate change at } \\
\text { sectoral level } \\
\text { - Training courses available for } \\
\text { government officials } \\
\text { - Joint programs and cooperation by } \\
\text { local institutions } \\
\text { Nursey-Bray (2017); } \\
\text { Mondal (2010) }\end{array}$ & $\begin{array}{l}\text { - Overemphasis on technological aspects } \\
\text { by local institutions } \\
\text { - Lack of acknowledgment of cultural } \\
\text { factors } \\
\text { - Failure of formal institutions to mediate } \\
\text { and link with informal institutions } \\
\text { - Occurrence of maladaptation by formal } \\
\text { institutes } \\
\text { - Lack of mainstreaming of climate } \\
\text { change in field activities } \\
\text { - Lack of investment for drought-prone } \\
\text { areas } \\
\text { - Low investment for capacity building } \\
\text { and institutional strengthening } \\
\text { - Lack of institutional control over pricing, } \\
\text { quality control and marketing of } \\
\text { agricultural produce }\end{array}$ & $\begin{array}{l}\text { Faisal (2017); } \\
\text { Haq and } \\
\quad \text { Rabbani } \\
\quad(2011) ; \\
\text { Islam and }\end{array}$ \\
\hline Technical & $\begin{array}{l}\text { - Gradual advancement in crop } \\
\text { variety development } \\
\text { - Rapid extension of mechanized } \\
\text { agriculture } \\
\text { - Beneficial return from investments } \\
\text { in agricultural research } \\
\text { - Development in ICT and improved } \\
\text { access to the internet }\end{array}$ & $\begin{array}{l}\text { - Lack of advanced research equipment } \\
\text { - Lack of resources for learning, accessing } \\
\text { global knowledge and databases, and } \\
\text { research } \\
\text { - Funding constraints and donor-driven } \\
\text { research } \\
\text { - Lack of advanced technologies for water } \\
\text { and soil management } \\
\text { - Limited access to existing facilities, } \\
\text { information, and technologies }\end{array}$ & $\begin{array}{l}\text { Haq (2017); } \\
\text { Mondal } \\
\quad(2010) ; \\
\text { Nagy (2000); } \\
\text { Ramos (2015); } \\
\text { Roy and Singh } \\
\quad(2008)\end{array}$ \\
\hline
\end{tabular}

complex options as well. It is a large-scale strategy, while also being highly out-system dependent, due to its political dimension. Dependence on such a highly out-system dependent strategy could increase future vulnerability, risk, and uncertainty. Moreover, since it is an offfarm strategy, local agronomic practices and water management could not fully rely upon it. This top-priority option was classified in the social and institutional management category. However, the currently most practiced options in this category, such as on-farm training programs, providing electricity, and establishing local cooperation for irrigation management, ranked much lower, 32nd, 23rd, and 47th in priority, respectively. 
The currently most practiced measures in the water management category, such as irrigation method adjustments, AWD, and dredging of river beds, were ranked 3rd, 5th, and 11th on the priority list, respectively. The top-ranked adaptation measure in the water management category was integrated water resources management (IWRM) practices. Indeed, Bangladesh has a long history of IWRM development, documented in the national Flood Action Plan (1989-1995), the Bangladesh Water and Flood Management Strategy (1995), the Ganges Water Treaty (1996), the National Policy for Safe Water Supply and Sanitation (1998), the National Water Policy (1999), the Guidelines for Participatory Water Management (2000), the National Water Resources Database (2001), the National Water Management Plan (2004), Regional Technical Assistance (2009), and the Bangladesh Water Act (2013) (Alam and Quevauviller 2014). IWRM is an on-farm strategy, meaning that it can be implemented autonomously by local water authorities and farmers. However, as a cross-sectorial policy approach, IWRM is a broad concept, and it is oftentimes difficult to define what aspects should be integrated, by whom, how, or even if such integration in a wider sense is possible (Biswas 2004). Furthermore, the future development and success of IWRM in the study region is not a given, due to the out-system dependence of this adaptation option. In addition, IWRM in Bangladesh has long been hampered by constraints such as insufficient participation of local stakeholders, uncoordinated planning and development, poor project conceptualization, lack of post-project evaluation, gaps between local initiatives and national projects, and high dependence on international donor funds (Das Gupta et al. 2005; Datta 1999; WARPO 1999). However, since several institutes in Bangladesh have been working on IWRM in recent years, progress may be forthcoming.

Several institutes have long been active in improving irrigation methods in Bangladesh. Barind Multipurpose Development Authority (BMDA) developed a low-cost channel system for water distribution. Rural Development Academy of Bogra implemented a buried pipe water distribution system. BADC has since constructed a number of large-scale buried pipelines. More recently, Bangladesh built 320 solar irrigation pumps benefiting 8000 farmers (World Bank 2016). Introduction of new irrigation methods is an on-farm strategy; therefore, local water managers and farmers at different locations can adjust their individual practices based on, for example, the types of crops they grow, soil conditions, farm structure, and power availability. Since changing irrigation methods is an in-system strategy, the further development and future success of this adaptation option is dependent on the experiences and attitudes of farmers and local water authorities.

The currently most practiced measures in the crop production management category, such as soil moisture conservation, non-rice grain cultivation, and adoption of suitable cropping patterns, were ranked 18th, 41st, and 12th on the priority list, respectively. Integrated crop management (ICM) was the top-priority adaptation option in the crop production management sector. Gaunt et al. (2000) confirmed the value of ICM at the farm level in Bangladesh. Several organizations, such as DAE, BRRI, and Proshika, have undertaken activities to implement ICM in the study region. In 2001-2004, BRRI in collaboration with the Rangpur Dinajpur Rural Service and Grameen Krishi Foundation implemented an ICM project in Northwest Bangladesh with one of its objectives being increased water use efficiency (Magor et al. 2007). ICM is a broadly conceptualized on-farm strategy that offers scope for combining local knowledge with ongoing research and new technologies. Moreover, it can be specifically tailored for different local conditions. Like IWRM, the further development and success of ICM is not a given in the study region, due to the out-system dependence of this adaptation option. Nonetheless, since several institutes are working on ICM, and farmers in Northwest 
Bangladesh have the capacity to adjust their operations and introduce changes over time, this option may show increasing promise in the coming years. However, since ICM is an on-farm strategy, its uptake may be hindered by social constraints, like poor economic conditions and farmers' lack of awareness, as well as the lack of facilities such as credit and information services for farmers. From an institutional perspective, ICM remains hampered by a lack of integration between the agricultural and water management sectors (Gaunt et al. 2000).

BDP2 100 (2017) developed adaptation pathways for Barind and other drought-prone areas of Bangladesh. Specifically, three independent strategies were proposed: (1) balancing water supply and demand, (2) minimizing water losses, and (3) ensuring water supply. Among the adaptation options in our inventory, the top three linked to BDP2100's first strategy are IWRM practices (ranked 2nd on our priority list), adjustment of irrigation methods (3rd on our list), and AWD for rice cultivation (5th priority on our list). The top three measures linked to BDP2100's second strategy are integrated crop management practices (4th on our priority list), education and research on climate-smart agriculture (7th on our list), and adjusting irrigation schemes (8th on our list). Linked to the third strategy, the top three measures from our inventory are transboundary cooperation (1st on our list), dredging of river beds (11th on our list), and rainwater harvesting and utilization (15th on our list).

\subsection{Complexities in implementing adaptation measures}

The findings of our study indicate a gap between what is required for successful climate adaptation and what is currently feasible in Northwest Bangladesh. Levels of social, institutional, and technical complexity were found to differ across the sector categories. For crop production management measures, social complexity, in terms of social acceptance, was higher than complexities related to technical aspects or institutional setup. The water management measures showed moderate technical, social, and institutional complexity. High technical and institutional complexity was found for the adaptation options in the social and institutional management category and in the education and research category. Land use and environmental management measures showed high technical, social, and institutional complexity. This is consistent with the feasibility study conducted by Gain et al. (2012), which identified weak local technical capacities for water management and lack of institutional coordination as the current main constraints to climate change adaptation in Bangladesh.

Our review of prospects and constraints in the social dimension indicates that provision of increased facilities for farmers (e.g., economic assistance, access to information) could boost social adaptive capacity, thus reducing social complexity. Since high social complexity was found for the adaptation options in the crop production, land use, water, and environmental management sectors, facilitation of farmers could go far to help overcome obstacles to adaptation in all these sectors. Our review of prospects and constraints related to the institutional dimension suggests that capacity building and mainstreaming of climate change adaptation would contribute to increase institutional capacity. Since there is high institutional complexity in every sector except crop production management (see Fig. 4), capacity building and mainstreaming climate change adaptation would contribute to all these sectors. Our review of prospects and constraints in the technical dimension indicates that resource development (e.g., research facilities, data availability) would help build technical capacity. Technical resource development would particularly support adaptation in the land, water, and environmental management sectors. 


\subsection{Required actions toward effective planning}

This study found a preference among stakeholders for higher scale out-system dependent options aimed at minimizing the impacts of climate change on agricultural systems in Northwest Bangladesh, rather than in-system dependent options focused on changing the agricultural or water management system itself to cope with climate change impacts. This is surprising, as there is ample opportunity within the present agronomic system to adapt to projected changes, with predictable outcomes and success. In contrast, the preferred higher scale out-system dependent strategies are all complex to implement and reliant on "outsiders" for success. Investment in adaptation of the agricultural system seems a much safer option. It is essential to emphasize this among stakeholders and institutions, as the failure of complex adaptation options would have far-reaching impact on local production systems. It is therefore recommended that short-term and medium-term planning be oriented toward opportunities to implement achievable adaptation measures within the local agricultural system with a clear view of success.

For long-term planning, it is essential to transform the complex options into feasible measures through capacity building at the national and local levels, and by mainstreaming climate change adaptation in the development process. A framework proposed by Huq and Ayers (2008) to build national capacity for mainstreaming climate change adaptation could be effective in this regard. As the different categories of adaptation options showed different types and levels of complexity, specific objectives for capacity building are required to reduce the particular complexities of each. For example, crop production management showed a high level of social complexity. For this, capacity building in the form of increased social awareness and farmer training would be helpful.

\subsection{Implications, limitations, and scope for future research}

The findings of this research can be directly applied to support policy design and decisionmaking in Northwest Bangladesh. However, cost-benefit analysis of the prioritized measures should be done in the initial phase, before large-scale implementation begins. Once interconnections between the top-priority measures are clarified, development of a plan for a combined approach could promote sequential, simultaneous, and timely implementation. Moreover, a combined approach could ensure flexibility toward reaching targets. For example, identification of drought-resistant or temperature-tolerant varieties is closely linked to crop selection and cropping patterns. If research can develop a more drought-resistant and temperature-tolerant rice variety, then cropping patterns should be dominated by rice crops. Otherwise, crops should be planned that are already suitable for high-temperature climates, such as date palm.

Participation of the experts/stakeholders was a prerequisite for the MCA. Without their technical and economic evaluations, this study's assessment of the adaptation options would have been incomplete. However, their inputs can also point to options that need more attention in technical and economic research. The criteria selected for use in the MCA had the limitation of interdependency (Brooks et al. 2009). In view of these limitations, the ranking for Northwest Bangladesh presented in the current study should be read as an initial priority ranking for anticipatory adaptation planning. It is important to realize that the effectiveness of the different options in the various areas of Northwest Bangladesh could differ based on the degree of local climate change and soil and water availability. Therefore, technical studies during pilot projects are highly recommended. There is also scope for more research to link adaptation measures to higher level policy planning. 


\section{Conclusion}

This study identified and ranked adaptation options for better agricultural water management to cope with climate change in Northwest Bangladesh. Local experts/stakeholders mainly preferred integrated, cooperative, and advanced technical strategies that were out-system dependent. Most of the adaptation options chosen as top priorities involved high technical, social, or institutional complexity as well. Yet, options representing in-system dependent onfarm strategies could better ensure successful implementation and gradual development. Therefore, for short- and medium-term planning, prioritizing in-system dependent options over out-system dependent options is essential. Regarding long-term adaptation planning, actions are required to reduce the complexity of the top-priority climate adaptation options.

Acknowledgments The authors sincerely acknowledge the Nuffic NICHE-BGD-155 project for granting the fellowship to Tapos Kumar Acharjee for his PhD study at Wageningen University and Research, The Netherlands. We would also like to acknowledge Michelle Luijben for proofreading the article.

\section{Appendix}

Table 5 Adaptation options under crop production management category

\begin{tabular}{llll}
\hline & Adaptation options & Priority & Complexity \\
\hline 1 & Identification and adoption of suitable cropping patterns & 3.71 & 2.74 \\
2 & Adjusting planting times of different crops and varieties & 3.50 & 2.57 \\
3 & Choice of drought-resistant and high-temperature-tolerant crop varieties & 3.77 & 2.71 \\
4 & Development and growing of crops for biomass production & 2.12 & 2.90 \\
5 & Soil moisture conservation practices, e.g., mulching & 3.65 & 2.39 \\
6 & Dry direct seeded rice production technology & 2.39 & 2.53 \\
7 & Zero and minimum tillage to reduce soil and water losses & 2.91 & 2.97 \\
8 & Wide row spacing to increase rainfall utilization & 2.70 & 2.65 \\
9 & Strip intercropping with crops of different root systems to maximize soil water utilization & 2.74 & 2.84 \\
10 & Transplantation at deeper depths for better root proliferation and to facilitate moisture extraction & 2.03 & 2.80 \\
& during drought & 2.48 & 2.54 \\
11 & Adoption of more intense rice cropping system & 2.89 & 2.67 \\
12 & More fruit cultivation instead of rice & 2.88 & 2.46 \\
13 & More vegetable cultivation instead of rice & 3.15 & 2.30 \\
14 & Non-rice grain cultivation instead of rice & 2.59 & 3.34 \\
15 & Construction of greenhouses/crop houses for fruits and vegetable cultivation & 4.00 & 2.69 \\
16 & Integrated crop management (ICM) practices & 3.26 & 2.83 \\
17 & Close monitoring and evaluation of farming activities & 3.46 & 2.21 \\
18 & Rainfed crop cultivation & &
\end{tabular}

Table 6 Adaptation options under land use management category

\begin{tabular}{lllc}
\hline & Adaptation options & Priority & Complexity \\
\hline 19 & Relocation or mobilization of farms & 2.03 & 3.58 \\
20 & Restructuring of agricultural lands & 2.48 & 3.17 \\
21 & Increasing croplands by clustering scattered households & 2.97 & 3.86 \\
22 & Reallocation of nursery plots & 1.79 & 2.31 \\
23 & Conservation of agricultural lands & 3.90 & 2.59 \\
24 & Char land and riverbank management & 3.67 & 2.98 \\
25 & Hilly land management & 3.24 & 3.06 \\
\hline
\end{tabular}


Table 7 Adaptation options under water management category

\begin{tabular}{|c|c|c|c|}
\hline & Adaptation options & Priority & Complexity \\
\hline 26 & Adjusting irrigation scheme; irrigation system evaluation and adjustment & 3.84 & 2.65 \\
\hline 27 & Adjustment of irrigation method, e.g., drip, sprinkler, or buried pipe irrigation & 4.03 & 2.70 \\
\hline 28 & Rainwater harvesting and utilization & 3.69 & 2.68 \\
\hline 29 & Integrated water resources management (IWRM) practices & 4.07 & 2.77 \\
\hline 30 & Deficit irrigation practices for optimum economic benefit & 3.11 & 2.70 \\
\hline 31 & Alternate wetting and drying (AWD) method for rice cultivation & 3.93 & 2.01 \\
\hline 32 & Dredging of river beds to support surface water flows and increase water storage & 3.73 & 2.96 \\
\hline 33 & Reconnection of water systems & 3.10 & 3.32 \\
\hline 34 & Construction of more sluices and weirs & 2.67 & 2.88 \\
\hline 35 & Construction and re-excavation of canals and other water conveyance structures & 3.42 & 2.64 \\
\hline 36 & Enhancing capacity of sluices and weirs & 2.75 & 2.58 \\
\hline 37 & Using wastewater for irrigation, especially during droughts & 3.01 & 2.57 \\
\hline 38 & Re-excavation of traditional ponds & 3.00 & 2.09 \\
\hline 39 & Maintain higher groundwater table by limiting water withdrawals & 3.52 & 2.99 \\
\hline 40 & $\begin{array}{l}\text { Fair (re)allocation of water among different sectors, e.g., domestic uses, industry, and } \\
\text { agriculture }\end{array}$ & 2.83 & 3.11 \\
\hline 41 & Fair (re)allocation of water among different regions (more to drought-affected areas) & 2.52 & 3.35 \\
\hline 42 & Risk-based water allocation policy & 2.71 & 3.08 \\
\hline 43 & Adopting water measurement measures to increase water productivity & 3.66 & 2.54 \\
\hline 44 & Water pricing to minimize water losses and reduce water market monopoly & 3.40 & 2.75 \\
\hline
\end{tabular}

Table 8 Adaptation options under environmental management category

\begin{tabular}{llll}
\hline & Adaptation options & Priority & Complexity \\
\hline 45 & Reduced fertilizer application to reduce water pollution & 3.20 & 2.79 \\
46 & Waste management to reduce water pollution & 3.54 & 3.46 \\
47 & Reduced groundwater withdrawals to reduce groundwater pollution & 3.06 & 2.87 \\
48 & Implementation of effective agro-environmental schemes & 3.21 & 3.31 \\
49 & Integrated nature and water management & 3.25 & 2.75 \\
50 & Restoration of ecosystems & 3.21 & 3.50 \\
51 & Afforestation, forest management, and mix of tree species & 3.11 & 2.53 \\
52 & Monitoring nature, interpreting changes, and informing & 2.81 & 2.91 \\
53 & Establishment and management of protected areas & 2.80 & 2.97 \\
\hline
\end{tabular}

Table 9 Adaptation options under social and institutional management category

\begin{tabular}{llcc}
\hline & Adaptation options & Priority & Complexity \\
\hline 54 & New institutional alliances/associations & 2.57 & 2.97 \\
55 & Insurances against drought-related damages or financial incentives for drought-period & 3.20 & 2.71 \\
& $\quad$ farming & & \\
56 & Providing electricity to underdeveloped areas for running pumps during dry periods & 3.51 & 2.53 \\
57 & Establishing area-based local cooperation for irrigation system management and & 3.06 & 2.54 \\
& monitoring & 4.39 & 3.34 \\
58 & Transboundary cooperation to increase surface water flows & 3.35 & 2.59 \\
59 & Cooperation of local stakeholders for surface water management & 3.23 & 2.79 \\
60 & Infrastructural development for irrigation and farm management & 3.35 & 1.97 \\
61 & Training programs for on-farm water management & 3.41 & 2.40 \\
62 & Developing meteorological stations to support better forecasting & 3.15 & 2.33 \\
63 & Stimulating exchange of results and ideas between different projects & 2.84 & 2.50 \\
64 & Promoting non-crop agriculture along with crop agriculture & 3.70 & 3.34 \\
65 & Climate risk management measures & 3.54 & 2.50 \\
66 & Farmers' participatory approach for learning and adopting new technologies &
\end{tabular}


Table 10 Adaptation options under education and research category

Adaptation options

67 Development and dissemination of updated irrigation technologies

68 Research on local drought management

69 Education and research on climate-smart agriculture

70 Education and research on conservation agriculture

71 Education and research on integrated water resources management (IWRM)

72 Training program for local farmers to deal with climate change and local water management
Priority Complexity

$\begin{array}{ll}3.82 & 2.54 \\ 3.42 & 2.57 \\ 3.84 & 2.68 \\ 3.35 & 2.56 \\ 3.70 & 2.71 \\ 3.54 & 2.30\end{array}$

2.54

2.68

2.56

2.71

2.30

\section{References}

Adger WN, Huq S, Brown K, Conway D, Hulme M (2003) Adaptation to climate change in the developing world. Prog Dev Stud 3:179-195

Adger WN, Dessai S, Goulden M, Hulme M, Lorenzoni I, Nelson DR, Naess LO, Wolf J, Wreford A (2009) Are there social limits to adaptation to climate change? Clim Chang 93:335-354

Adham MI, Jahan CS, Mazumder QH, Hossain MM, Haque AM (2010) Study on groundwater recharge potentiality of Barind Tract, Rajshahi District, Bangladesh using GIS and remote sensing technique. J Geol Soc India 75(2):432-438

Agrell PJ, Lence BJ, Stam A (1998) An interactive multicriteria decision model for multipurpose reservoir management: the Shellmouth Reservoir. J Multi-Criteria Decis Anal 7:61-86

Alam M, Quevauviller P (2014) An evaluation of Integrated Water Resources Management (IWRM) activities in Bangladesh. Asia Pacific J Energy Environ 1:22-38

Almasri MN, Kaluarachchi JJ (2005) Multi-criteria decision analysis for the optimal management of nitrate contamination of aquifers. J Environ Manag 74:365-381

Anik SI, Khan MASA (2012) Climate change adaptation through local knowledge in the north eastern region of Bangladesh. Mitig Adapt Strateg Glob Chang 17:879-896

BDP2100 (2017) Bangladesh Planning Commission. Bangladesh Delta Plan 2100

Bierbaum R, Stults M (2013) Adaptation to climate change: context matters. Michigan J Sustain, 1

Biswas AK (2004) Integrated water resources management: a reassessment: a water forum contribution. Water Int 29:248-256

Boettle M, Schmidt-Thomé P, Rybski D (2013) Coastal protection and multi-criteria decision analysis: didactically processed examples. Climate change adaptation in practice: from strategy development to implementation, 35-49

Brooks M, Gagnon-Lebrun F, Harvey H, Sauvé C (2009) Prioritizing climate change risks and actions on adaptation, a review of selected institutions, tools, and approaches. Government of Canada, Ottawa

Champalle C, Ford JD, Sherman M (2015) Prioritizing climate change adaptations in Canadian Arctic communities. Sustainability 7:9268-9292

Chowdhury NT (2010) Water management in Bangladesh: an analytical review. Water Policy 12:32-51

Christensen JH, Hewitson B, Busuioc A, Chen A, Gao X, Held R, Jones R, Kolli RK, Kwon WK, Laprise R, Magaña Rueda V (2007) Regional climate projections. In climate change, 2007: the physical science basis. Contribution of Working group I to the Fourth Assessment Report of the IPCC, Chapter 11, 847-940

Das Gupta A, Singh Babel M, Albert X, Mark O (2005) Water sector of Bangladesh in the context of integrated water resources management: a review. Int J Water Resour Dev 21:385-398

Datta AK (1999) Planning and management of water resources: lessons from two decades of early implementation projects. Dhaka University Press, Bangladesh

de Bruin K, Dellink R, Ruijs A, Bolwidt L, Van Buuren A, Graveland J, De Groot R, Kuikman P, Reinhard S, Roetter R (2009) Adapting to climate change in The Netherlands: an inventory of climate adaptation options and ranking of alternatives. Clim Chang 95:23-45

Dey NC, Bala SK, Islam AK, Rashid MA, Hossain M (2013) Sustainability of groundwater use for irrigation in northwest Bangladesh. Policy report prepared under the National Food Policy Capacity Strengthening Programme (NFPCSP). Dhaka, Bangladesh, 89

Faisal AM (2017) Capacity building: achievements, lessons and policy recommendations, Dhaka Tribune. Published on April 13th, 2017. https://www.dhakatribune.com/tribune-supplements/tribune-climate/2017 $/ 04 / 13 / 57821$ 
Feenstra JF (1998) Handbook on methods for climate change impact assessment and adaptation strategies. Published by United Nations Environment Programme and Institute for Environmental Studies, Vrije Universiteit

Füssel H-M (2004) Conceptual frameworks of adaptation to climate change and their applicability to human health. Potsdam-Institut fuer Klimafolgenforschung e.V, Potsdam ISSN 1436-0179

Füssel H-M (2007) Adaptation planning for climate change: concepts, assessment approaches, and key lessons. Sustain Sci 2:265-275

Füssel H-M (2009) Ranking of national-level adaptation options. An editorial comment. Clim Chang 95:47-51

Gain AK, Giupponi C, Renaud FG (2012) Climate change adaptation and vulnerability assessment of water resources systems in developing countries: a generalized framework and a feasibility study in Bangladesh. Water 4:345-366

Gaunt J, Best J, Hossain Z, Norrish P, Robinson E, Sutherland A, White S (2000) The feasibility of Integrated Crop Management in Bangladesh, p 41

Greco S, Ehrgott M, Figueira J (2016) Multiple criteria decision analysis : state of the art surveys. Springer

Habiba U, Shaw R, Takeuchi Y (2012) Farmer's perception and adaptation practices to cope with drought: perspectives from northwestern Bangladesh. Int J Disaster Risk Reduction 1:72-84

Haq S (2017) Capacity building to address climate change, Dhaka Tribune. Published on May 10th, 2017. https:/www.dhakatribune.com/tribune-supplements/tribune-climate/2017/05/10/capacity-building-addressclimate-change. Accessed 12/10/2018

Haq S, Rabbani G (2011) Climate change and Bangladesh: policy and institutional development to reduce vulnerability. J Bangladesh Stud 13:1-10

Huq S, Ayers J (2008) Streamlining adaptation to climate change into development projects at the national and local level. Financing climate change policies in developing countries. European Parliament, Brussels, 5268

Islam MT, Nursey-Bray M (2017) Adaptation to climate change in agriculture in Bangladesh: the role of formal institutions. J Environ Manag 200

Joubert A, Stewart TJ, Eberhard R (2003) Evaluation of water supply augmentation and water demand management options for the City of Cape Town. J Multi-Criteria Decis Anal 12:17-25

Lim B, Spanger-Siegfried E, Burton I, Malone E, Huq S (2005) Adaptation policy frameworks for climate change: developing strategies, policies and measures. Cambridge University Press, Cambridge

Lobell DB, Burke MB, Tebaldi C, Mastrandrea MD, Falcon WP, Naylor RL (2008) Prioritizing climate change adaptation needs for food security in 2030. Science 319:607-610

Magor N, Salabuddin A, Haque M, Biswas T, Bannerman M (2007) PETRRA-an experiment in pro-poor agricultural researc. Int. Rice Res. Inst

Mondal MH (2010) Crop agriculture of Bangladesh: challenges and opportunities. Bangladesh J Agric Res 35: 235-245

Nagy JG (2000) Impact of agriculture research in Bangladesh, estimating returns to agricultural research. Bangladesh Agricultural Research Management Project (ARMP), BARC and IFDC

Noble I, Huq S, Anokhin YA, Carmin J, Goudou D, Lansigan FP, Osman-Elasha B, Villamizar A (2014) Adaptation needs and options, in: Field CB, Barros VR, Dokken DJ, Mach KJ, Mastrandrea MD, Bilir TE, Chatterjee M, Ebi KL, Estrada YO, Genova RC, Girma B, Kissel ES, Levy AN, MacCracken S, Mastrandrea PR, White LL (Eds.), Climate change 2014: impacts, adaptation, and vulnerability. Part A: global and sectoral aspects. Contribution of Working Group II to the Fifth Assessment Report of the IPCC. Cambridge University Press, Cambridge, United Kingdom and New York, NY, USA, 833-868

Raju K, Kumar DN (1999) Multicriterion decision making in irrigation planning. Agric Syst 62:117-129

Ramos YJR (2015) Science and technology for development in Bangladesh and Nepal: key topics, challenges and opportunities, SciDev.Net Learning Series. SciDev.Net

Reilly J (1995) Climate change and global agriculture: recent findings and issues. Am J Agric Econ 77:727-733

Roy K, Singh G (2008) Agricultural mechanization in Bangladesh. AMA, Agric Mech Asia, Afr Latin Am 39:83

Selvaraju R, Baas S (2007) Climate variability and change: adaptation to drought in Bangladesh: a resource book and training guide. FAO, 9

Shahid S (2008) Spatial and temporal characteristics of droughts in the western part of Bangladesh. Hydrol Process 22(13):2235-2247

Shahid S, Behrawan H (2008) Drought risk assessment in the western part of Bangladesh. Nat Hazards 46(3): $391-413$

Shahid S, Hazarika MK (2010) Groundwater drought in the northwestern districts of Bangladesh. Water Resour Manag 24(10):1989-2006

Shepherd P, Tansey J, Dowlatabadi H (2006) Context matters: What shapes adaptation to water stress in the Okanagan? Climatic Change 78(1):31-62

Smit B, Pilifosova O (2003) Adaptation to climate change in the context of sustainable development and equity. Sustain Dev 8:9 
Smit B, Wandel J (2006) Adaptation, adaptive capacity and vulnerability. Glob Environ Chang 16:282-292 Swart ROB, Raes F (2007) Making integration of adaptation and mitigation work: mainstreaming into sustainable development policies? Clim Pol 7(4):288-303

WARPO (1999) Review of planned and actual O\&M of water sector projects, Working Paper 8.05, Water Resources Planning Organization

Willows R, Reynard N, Meadowcroft I, Connell R (2003) Climate adaptation: risk, uncertainty and decisionmaking. UKCIP Technical Report. UK Climate Impacts Programme

World Bank (2016) Bangladesh: building resilience to climate change. Published on October 9th, 2016. https:/www.worldbank.org/en/results/2016/10/07/bangladesh-building-resilience-to-climate-change

Publisher's note Springer Nature remains neutral with regard to jurisdictional claims in published maps and institutional affiliations.

\section{Affiliations}

\section{Tapos Kumar Acharjee ${ }^{1}$ - Petra Hellegers ${ }^{2} \cdot$ Fulco Ludwig $^{3} \cdot$ Gerardo van Halsema $^{2}$. Md. Abdul Mojid ${ }^{1} \cdot$ Catharien Terwisscha van Scheltinga $^{4}$}

1 Department of Irrigation and Water Management, Bangladesh Agricultural University, Mymensingh, Bangladesh

2 Water Resources Management Group, Wageningen University, Wageningen, The Netherlands

3 Water Systems and Global Change Group, Wageningen University, Wageningen, The Netherlands

4 Wageningen Environmental Research (Alterra), Wageningen, The Netherlands 